\title{
IMPLICATION OF ISLAMIC COUNSELING FOR KODAM I/BUKIT BARISAN SOLDIERS
}

\author{
Saiful Akhyar Lubis ${ }^{1}$, Abdurrahman ${ }^{2}$, Syawal Fahmi ${ }^{3}$ \\ ${ }^{1,2,3}$ State Islamic University of North Sumatra, Medan, Indonesia \\ *Korespodensi: fahmi23868@gmail.com
}

\begin{abstract}
ABSTRACK
This study aims to determine the implications of Islamic counseling in mentoring mentors of Kodam I/Bukit Barisan. Data collection methods in this study used qualitative analysis with observation, interview, and documentation techniques. The results showed that the implications of Islamic counseling for Kodam I Bukit Barisan soldiers functioned as enlightenment for soldiers who have problems in life. At the same time Islamic counseling also plays a role in minimizing the occurrence of violations of work discipline and moral violations of soldiers when they are on duty, as well as when they are in the community. Thus it can be assumed that the role of Islamic counseling for Kodam I Bukit Barisan soldiers is very significant in supporting the smooth running of their duties.
\end{abstract}

Keyword: Counseling, Islamic, soldiers.

\begin{abstract}
ABSTRAK
Penelitian ini bertujuan untuk mengetahui implikasi konseling Islam dalam pendampingan pendamping Kodam I/Bukit Barisan. Metode pengumpulan data dalam penelitian ini menggunakan analisis kualitatif dengan teknik observasi, wawancara, dan dokumentasi. Hasil penelitian menunjukkan bahwa implikasi penyuluhan Islam bagi prajurit Kodam I Bukit Barisan berfungsi sebagai pencerahan bagi prajurit yang memiliki masalah dalam kehidupan. Pada saat yang sama penyuluhan Islam juga berperan dalam meminimalisir terjadinya pelanggaran disiplin kerja dan pelanggaran moral prajurit saat bertugas, maupun saat berada di masyarakat. Dengan demikian dapat diasumsikan bahwa peran Bimbingan Islam bagi Prajurit Kodam I Bukit Barisan sangat signifikan dalam menunjang kelancaran tugasnya.
\end{abstract}

Kata Kunci: Konseling, Islam, Prajurit.

\section{A. PENDAHULUAN}

Islamic counseling functions as a means of helping the communication of someone who has psychiatric disorders to get help in healing. Islamic character counseling is not something new. As an approach that directly touches the psychic life of man, he has existed since the first time the Prophet Muhammad assumed his apostolic task. At that time it was found that counseling services in the form of counseling were prominent and dominant activities. Activities or services carried out by the Prophet to his companions can be recorded as interactions that take place between counselor and counselee (Lubis, 2017: 3).

Therefore, Islamic counseling and mental health are two things that are very related and can not be separated in the lives of every Muslim. Humans in carrying out their daily activities are inseparable from the problems they face. For this reason Islamic counseling exists as an 
intermediary bridge to deliver people to intelligent solutions and in accordance with religious demands. Islam is present as a compass to guide people in all things. Therefore sorting out and separating between world and religious affairs is a big mistake. So it is with Islamic counseling and mental health.

In the military world, mental training is a mandatory program that must be followed by every soldier and the State Civil Apparatus (ASN) who are members of the Army organization. Specifically Kodam I / Bukit Barisan has 77 personnel of Bintaldam personnel (Bukit Barisan Kodam Document, 2019). This considerable amount is a force that can maximize the task and function of the mental guidance of Kodam I / Bukit Barisan soldiers. Bintaldam is tasked with organizing the mental training of soldiers and ASN Kodam I / Bukit Barisan and their families as well as preservation and inheritance of historical values in order to support the main tasks of Kodam I / Bukit Barisan which are carried out routinely and structured every month.

One of the functions of Bintaldam is to provide guidance to soldiers with a counseling approach, this has long been done at every level of the organization of the Army. The aim is that the soldiers can carry out their duties and services as well as possible, and work with minimal violations. Therefore, the counseling services in the Kodam I / Bukit Barisan unit want researchers to see and develop based on the character of Islamic counseling, so that the counseling that has been done can be more effective and efficient.

From here then researchers are interested in making a research study on Islamic counseling in the mental development of warriors. To differentiate from previous research, the specifications in this study are researchers trying to combine Islamic counseling with mental coaching. For this reason, researchers are interested in taking a research theme entitled "Implications of Islamic Counseling in the Mental Development of Kodam I / Bukit Barisan Soldiers".

\section{B. THEORYTICAL STUDY}

\section{Islamic Counseling}

In Arabic literature the word counseling is called al-irshad or alistisyarah, and the word guidance is called al-taujih. Etymologically the word al-irshad means al-huda, addalalah which means in Indonesian is a guide, while al-istisyarah means talaba min al-masyurah / al-nasihah which means asking for advice or consultation (Lubis, 2017: 56-57).

In the Qur'an the word al-irshad is found to be one with al-huda in surah al-kahfi (18) 
verse 17, It means: "Who is guided by Allah, then He is the one who gets instructions; and whoever deceives him, then you will not find a leader who can give him instructions. "

Likewise the word al-irshad is contained in surah al-Jin (72) verse 2, Meaning: "(who) give directions to the right path, then We have faith in him."

Zarnuji uses the word al-irshad with the intention of giving clues to the context of the learning method (memorization) he describes.

In essence, Islamic counseling is not new, but it has existed along with the transmission of Islamic teachings to the Messenger of Allah. for the first time. When it is an educational tool in the spiritual system that God provides guidance (guidance) for the requesters guidance (guidance).

The Prophet's practices in resolving the problems faced by his companions at that time could be noted as an ongoing interaction between counselor and client / counselee, both in groups (for example in the halaqah ad-dasrs model) and individually. Services with counseling models during the time of the Prophet were mainly driven by problematic community conditions and were born from an established jahiliyah culture. The word iqra, which Allah chose as the initial word and as a key word for Muhammad's apostolic mission, is a meaningful conditional reality.

From the opinion above, it is clear that there is a firmness that Islam is a religion of science, in the sense of a religion that upholds the value of science, teaches the principles of science to deliver people to the level of intelligence. The level of intelligence and knowledge possessed by a person will determine the height of his degrees in the eyes of humans and before God. Islam is also a religion of light, in the sense that scientific instructions and cues are taught that it will become a guide for humans to explore their way of life towards the ultimate goal of life in accordance with God's wishes (happiness of the world and the hereafter).

From the information above it is clearly seen that Islamic counseling is a counseling process oriented to the peace of life of the afterlife. Achieving a sense of calm (sakinah) is through efforts to obtain His protection. Sakinah therapy will deliver the individual to work alone and be able to solve the problems of his life. Thus, it is explicitly said that Islamic counseling contains a spiritual dimension and a material dimension. The spiritual dimension is to guide people in their spiritual life to be faithful and to fear Allah. While the material dimension helps humans to be able to solve life's problems in order to achieve progress. These 
principles clearly distinguish the concept of western counseling from the concept of Islamic counseling (Lubis, 2017: 63).

Islamic counseling that is built on psychological principles in Islam has an essential difference from counseling that is built on a speculative empirical foundation, because Islamic counseling is a form of actualization of the completeness and perfection of Islamic teachings themselves. In connection with this, Hasan Muhammad Asy-Syarqawi's opinion can be seen which explains the difference between Islamic Psychology and Western Psychology. The difference lies in the attitude of total surrender to God with faith for the realization of mental health. By always following God's instructions, the human heart will be at peace because it is illuminated by light, divine light.

\section{b. The Purpose of Islamic Counseling}

Broadly speaking or in general, the goal of Islamic counseling can be formulated as "helping individuals realize themselves as fully human beings in order to achieve happiness in life in the world and the hereafter (Musnamar, 1992: 33). General objectives of counseling according to Munandar (1997) \& Assingkily \& Mikyal (2019) include:

1. Assist the intellectual, emotional, and social development of students;
2. Help prevent disruption or problems in the development of students;

3. Helping problems experienced by students.

While the specific purpose of counseling is a translation of the general purpose of counseling that is directly related to the problems experienced by the individual concerned, according to the complexity of the problem.

Based on the general and specific objectives above, the objectives of Islamic counseling can be formulated to help individuals realize themselves as fully human beings in accordance with the positive demands of their environment and achieve happiness in the life of the world and the hereafter. The journey of human life, especially students who are studying sometimes face a problem, especially if it is heavy, then Islamic counseling basically only helps students to know the problems they face, or know the condition of their strengths and weaknesses, and help find alternative solutions based on teaching Islam through patience and efforts to find the right method for solving the problem. This concept according to Islam is contained in the Qur'an, Allah swt. Said, It means: "And truly we will give you trials, with a little fear, hunger, lack of wealth, soul and fruit. And give good news to people who are patient." 
Based on these concepts the objectives of Islamic counseling include:

1. Helping students prevent the emergence of problems related to learning / education activities;

2. Helping students solve problems related to learning / education;

3. Helping students maintain the situation and condition of learning / education activities in order to stay good and develop it to be even better.

The development of human civilization, as we have seen today, has proven mankind that man is the ruler of the earth (caliph). Various advances in technological science have played a major role in cultural change and human attitudes are changing more and more rapidly. The progress of such a civilization does not always make people happy, calm and safe. Various problems accompany the progress of human civilization, starting with environmental problems, increasingly rampant crime and various forms, family poisoning, political problems, economic crises, and security issues that are difficult to predict. Such problems, sooner or later, whether they realize it or not, have affected human psychology. Psychic problems as the core of human beings bring changes to lifestyle and everyday lifestyle (Arifin, 2009: 1).

Due to the rapid advancement of science and technology, job opportunities also develop rapidly, so students need help from mentors to adjust their interests and abilities to the ever changing and expanding world of work opportunities.

Equal opportunity for everyone has become a reality in various fields, both schools, universities, other universities, factories and industries, as well as among professionals (Nurihsan, 2006: 2). Everyone is required to be able to respond quickly and precisely all the negative impacts caused, both for themselves and for others. Especially with the development of the world of education, distance, space and time are no longer a barrier for humans to know what is happening in various parts of the world. For example, events abroad and within the country can be accessed quickly through a sophisticated electronic media.

Therefore, counseling services are needed as a means to help students to avoid missteps in addressing the increasingly sophisticated world. The students referred to here are not only students in formal education (school), but also in non-formal education (outside school) and informal (family environment), even for teachers, tutors, teacher candidates, tutor candidates, and does not rule out the possibility for the students parents and community (Sutirna, 2012: 1). 


\section{c. Mental Development}

Mental is all the elements of the soul including thoughts, emotions, attitudes, and feelings in its entirety and roundness will determine the pattern of behavior, how to deal with something that suppresses feelings, disappoints or encourages, pleases and so on (Daradjat, 1982: 38-39; Lubis, et.al., 2020). Mental spiritual development is all efforts to maintain, increase faith and piety, enhance morals in human relations with God, each other and with the environment (Munib, 2016: 89).

Human mental structure is built on three things. First, the way of thinking (mindset); both ways of believing (transcendental value); third way to behave (behavioral approach). From these three stages a good mentality is manifested in the form of behavior. Amanah development and strengthening of mental character (Suwardana, 2017: 105). This is what is important to pay attention to so that mental coaching becomes more directed and successful.

Mental health is the avoidance of people from symptoms of mental disorders (neurose) and from symptoms of mental illness (psychosce). The above definition received a lot of response from the Psychiatric (psychiatric). According to this definition, people who are mentally healthy are people who avoid all mental disorders. What is meant by mental disorders we will peel specifically in the following chapters. But in a nutshell it can be said that people suffer from mental disorders when: often anxious without knowing why, lazy, no excitement to work, feeling fit and so on. These symptoms in the advanced stages are found in anxiety, neurasthenia, hysteria and so on. While mental illness is a person whose views are far different from views in general, far from reality, which in everyday terms we know oblique, crazy, and so on (Daradjat, 1990: 11).

Mental health is the avoidance of people from symptoms of mental disorders (neurose) and from symptoms of mental illness (psychosce). The above definition received a lot of response from the Psychiatric (psychiatric). According to this definition, people who are mentally healthy are people who avoid all mental disorders. What is meant by mental disorders we will peel specifically in the following chapters. But in a nutshell it can be said that people suffer from mental disorders when: often anxious without knowing why, lazy, no excitement to work, feeling fit and so on. These symptoms in the advanced stages are found in anxiety, neurasthenia, hysteria and so on. While mental illness is a person whose views are far different from views in general, far from reality, which in 
everyday terms we know oblique, crazy, and so on (Daradjat, 1990: 11).

The main problem that determines whether a nation is progressing or not is the issue of human resources (HR). It seems that Indonesian human resources are mostly still at a fairly low level. This is because a small portion of Indonesian people can enjoy higher education. The factor of natural wealth is the main source of less productive Indonesian society. Thus, president Ir. Joko Widodo often conveyed the idea of the importance of a mental revolution. The arguments conveyed by the change must be for the better not only in institutions and bureaucracy but also changes in the mentality of the people.

\section{d. Healthy Mental Characteristics}

According to Pieter (2011) explains that there are several characteristics for a healthy mental and unhealthy. Healthy mental characteristics, including:

1. Being able to assess yourself realistically; Being able to assess themselves as they are about their strengths and weaknesses, physically, knowledge, skills and so on;

2. Being able to assess the situation realistically; can deal with situations or conditions of life they experience realistically and are willing to accept fairly, do not expect the conditions of life as something perfect;

3. Able to assess the achievements obtained realistically; can assess the success he gets and react rationally, not to be arrogant, haughty or to experience superiority complex, if he gets high achievements or life success. If it fails, it doesn't react with frustration, but with optimism;

4. Accept responsibility; he has confidence in his ability to overcome the problems of life he faces;

5. Independence; has an independent nature in the way of thinking, and acting, able to make decisions, direct and develop themselves and adjust to the norms prevailing in their environment;

6. Can control emotions; feel comfortable with his emotions, can deal with situations of frustration, depression, or stress positively or constructively, not destructively (damaging);

7. Goal oriented; can formulate goals in every activity and life based on careful consideration (rationally), not on the basis of coercion from outside, and trying to achieve goals by developing personality (insight), knowledge and skills;

8. Oriented outward (extroverted); are respectful, empathetic towards others, have concern for the situation or 
environmental problems and are flexible in thinking, respecting and valuing others like themselves, feeling comfortable and open to others, not allowing themselves to be used to be victims of others and sacrifice others, because of his disappointment;

9. Social acceptance; willing to participate actively in social activities and have a friendly attitude in dealing with others;

10. Has a philosophy of life; directing his life based on the philosophy of life that is rooted in the religious beliefs that he adheres to;

11. Be happy; his life situation is colored by happiness, which is supported by achievement factors, acceptance and affection.

Besides those mentioned above, mental health characteristics according to Rahayu (2009) include:

1. Emotional maturity, which includes three characteristics of a person's behavior and thoughts, namely having self-discipline, self-determination and independence;

2. The ability to accept reality;

3. Live together and work together with others, as well as;

4. Having a philosophy or outlook on life, namely having a philosophy of life that can always guide him to be on the right path, especially when facing or being in a situation that is disturbing or burdensome.

As for the unhealthy mental, there are also some characteristics, namely:

1. Easily angry (offended);

2. Showing concern and anxiety;

3. Often feel depressed (stressed or depressed);

4. Being cruel or happy to disturb others who are younger or towards animals;

5. Inability to avoid deviant behavior despite being warned or punished;

6. The habit of lying;

7. Hyperactivity;

8. Be hostile to all forms of authority;

9. Happy to criticize / mock others;

10. Difficulty sleeping;

11. Lack of sense of responsibility;

12. Often experience headaches (although the cause is not an organic factor);

13. Lack of awareness to obey religious teachings;

14. Pessimistic in facing life;

15. Less passionate (moping) in living life.

\section{e. Efforts to Create a Healthy Mental}

Speaking related to mental health, it is inseparable from a disturbed or unhealthy mentality, so it is necessary to do ways and efforts that can make mental health or improve mental health. Some of the usual ways for mental health are sufistic approaches. This approach is 
usually done because it is quicker to fix an unhealthy mentality because it directly penetrates one's spirituality. This method is commonly referred to as Sufi Therapy.

In Sufistic therapy / counseling there are levels that must be passed by someone undergoing therapy, namely takhalli (ridding oneself of despicable qualities), tahalli (filling oneself with commendable qualities) and tajalli (the reality of God) (Zaini, 2016: 216).

First, takhalli (emptying oneself from despicable qualities). Efforts to empty themselves from the attitude of dependence on the delights of worldly life. This will be achieved by distanceing oneself from immorality in all its forms and trying to subdue the impulse. According to the Sufis, immorality is basically divided into two, namely immoral immorality and immoral immorality. Birth immunity is all the despicable behavior that is done by members of birth, such as hands, mouth, and eyes. Maksatat inner is all the despicable behavior that is done by the inner members, namely the heart (Team Compiler, 2002: 47). The Koran has informed that a unique and effective method for overcoming feelings of sin, namely through repentance. Repent to Allah. will make sins forgiven and strengthen the hope of His pleasure in humans. This situation will ease the intensity of anxiety. Furthermore, repentance will usually encourage humans to correct and correct themselves so they do not fall into error and immorality for the second time. It will also help increase human appreciation for him and increase self-confidence and satisfaction with him.

Second, tahalli (adorn oneself with commendable qualities). Attempts adorn yourself with the nature and attitude and good deeds. Trying that in every movement the behavior always goes above the provisions of religion, both obligations that are external or birth obedience or those that are inner or inner obedience. What is meant by internal / outer obedience are formal obligations, such as prayer, fasting, zakat, and pilgrimage, while inner / inner obedience includes faith, sincerity, and solemnity. At this stage of tahalli the counselee / client is encouraged to fill in obedience on an ongoing basis and istikamah. Some therapies that can be done are as follows:

1. Therapy with prayer;

2. Therapy with Qur'an recitations;

3. Therapy with remembrance;

4. Therapy with prayer.

Third, tajalli (reality of God). The term Sufism means the appearance of God is absolute in the form of nature that is limited. The concept of Tajalli starts from the view that Allah Almighty. in His solitude (before this world existed) wanted 
to see Himself outside Himself. Therefore, he made this nature. So thus this nature is a mirror for Allah. When He wants to see Himself, He looks at nature. In another version it is explained that God wants to be known, so He also appeared in the form of tajalli. This is the final process in the Sufi approach. It is expected that counselees really have excellent mental health and healthy personalities.

\section{METHOD}

This study uses field research (field research) conducted directly to the location of the study (Subagyo, 1991: 109). This study uses qualitative research methods, the basis of this research because it can see problems that are holistic, complex, dynamic and full of meaning. In addition, researchers intend to understand the situation in depth, find patterns, hypotheses and theories. In this approach, researchers create a complex picture, examine words, detailed reports from the respondents' views, and conduct studies on natural situations (Iskandar, 2009: 11). The location of this study was conducted at Kodam I / Bukit Barisan, Jl. Gatot Subroto, KM. 7.5 Medan City, North Sumatra.

\section{RESULT AND DISCUSSION}

Based on the results of interviews, observations and documentation at Kodam
I / Bukit Barisan, the research results are obtained that the implications of Islamic for Kodam I Bukit Barisan soldiers are very significant influence on the attitudes and attitudes and behavior of soldiers in carrying out their duties as members of the Army. The mental condition of a solid soldier is motivated by a steady mental state as well. As a soldier who is a soldier, of course demanded to have discipline and loyalty to the duties and responsibilities. Success in this regard is strongly supported by a healthy mental state as well (Wakka, 2018: 2).

The implications of Islamic counseling for Kodam I Bukit Barisan soldiers were felt directly by the soldiers in terms of providing enlightenment to the problems experienced. In this context Binrohis (Islamic Spiritual Guidance), which is under the auspices of Bintal (Mental Guidance), conducts an Islamicbased counseling program. In relation to the Islamic counseling guidance process, its implementation must be carried out based on Islam which is sourced from the Qur'an and Hadith (Napitupulu, 2017: 36; Assingkily \& Baroroh, 2017; Assingkily, 2019, Assingkily, et.al., 2021). Thus, the Islamic counseling process is based on Islamic principles and values.

In addition, the implication of Islamic counseling felt directly by Kodam I / Bukit Barisan soldiers is to minimize 
the mistakes that are generally made by soldiers. Researchers found that the factors that influence the occurrence of lawlessness and discipline by soldiers, among others, are caused by the low awareness of practicing directed mental development patterns according to the concept of "Tri Tunggal Mental Development", which includes mental mental development, mental ideological guidance and mental tradition development in the unit's struggle. Through Islamic counseling guidance services conducted at Kodam I Bukit Barisan, the above problems can be minimized gradually and then eliminated.

This Islamic counseling is carried out by spiritual officers to soldiers who have problems that they want to tell to someone who is trusted to help get solutions. Islamic counseling activities are very helpful for soldiers who are experiencing problems both about the family, about economic life, and about service. It is hoped that after counseling soldiers can be more motivated to solve existing problems and can focus on working optimally (Sitorus, et.al., 2019: 93).

Counseling can provide a motivational spirit to be able to solve the problems faced in a good way, not by shortcuts. By using religious values in this case the religion of Islam which is sourced from the Holy Qur'an and Hadith of spiritual officers can provide spiritual splash to soldiers who are experiencing problems so that soldiers can hold fast to Islamic values in finding solutions to the problems being faced. Islamic counseling as intended by researchers here has not been widely used by soldiers as a way to ease the burden of life and overcome their problems.

\section{E. CONCLUSION}

Based on the results of interviews, observations, and documentation that researchers have done, this study can be concluded that the implications of Islamic counseling for Kodam I /Bukit Barisan soldiers function as enlightenment of soldiers who have problems in life. At the same time Islamic counseling also plays a role in minimizing the occurrence of violations of work discipline and violations of soldiers when they are on duty, as well as when they are in the community. As such, it can be assumed that the role of Islamic counseling for Kodam I /Bukit Barisan soldiers is very significant in supporting the smooth running of their duties.

\section{REFERENCES}

Arifin, Isep Zainal. (2009). Bimbingan Penyuluhan Islam. Jakarta: Raja Grafindo Persada. 
Assingkily, Muhammad Shaleh \& R Umi Baroroh. (2017). "Prototipe Living Qur'an Pendidikan Dasar di Madrasah Ibtidaiyah: Studi Kasus di MI Nurul Ummah Kotagede Yogyakarta” JOIES, 2(1). http://jurnalpps.uinsby.ac.id/index.php /joies/article/view/35.

Assingkily, Muhammad Shaleh. (2019).

“Living Qur'an as a Model of Islamic

Basic Education in the Industrial Era 4.0" Al Ibtida': Jurnal Pendidikan $\begin{array}{lll}\text { Guru } & \text { MI, }\end{array}$ http://www.syekhnurjati.ac.id/jurnal/i ndex.php/ibtida/article/view/3876.

Assingkily, Muhammad Shaleh \& Mikyal Hardiyati. (2019). “Analisis Perkembangan Sosial-Emosional Tercapai dan Tidak Tercapai Siswa Usia Dasar" Al-Aulad: Journal of Islamic Primary Education, 2(2). http://journal.uinsgd.ac.id/index.php/al -aulad/article/view/5210.

Assingkily, Muhammad Shaleh, et.al. (2021). 'Living Qur'an dan Hadis di Madrasah Ibtidaiyah (MI): Perspektif Teori Thomas Lickona" Al-Aulad: Journal of Islamic Primary Education, 4(1).

http://journal.uinsgd.ac.id/index.php/al -aulad/article/view/9828.

Daradjat, Zakiah. (1982). Pendidikan Agama dalam Pembinaan Mental. Jakarta: Bulan Bintang.
Daradjat, Zakiah. (1996). Kesehatan Mental. Jakarta: Gunung Agung.

Dokumen Rekapitulasi Kekuatan Prajurit TNI AD Bintaldam I/BB dan Pendidikan Militer Bulan Oktober 2019.

Dokumen Kalender Bintal Kodam I/Bukit Barisan.

Iskandar. (2009). Metodologi Penelitian Kualitatif. Jakarta: Gaung Persada.

Lubis, Rahmat Rifa'i, et.al. (2020). “Pembelajaran Al-Qur'an Era Covid19: Tinjauan Metode dan Tujuannya pada Masyarakat di Kutacane Aceh Tenggara" Kuttab: Jurnal Ilmu Pendidikan Islam, 4(2). http://journalfai.unisla.ac.id/index.php /kuttab/article/view/275.

Lubis, Syaiful Akhyar. (2017). Konseling Islami: Dalam Komunitas Pesantren. Medan: Perdana Publishing.

Lubis, Syaiful Akhyar. (2017). Konseling Islami dalam Komunitas Pesantren. Bandung: Citapustaka Media Perintis. Musnamar, Thohari. (1992). "Prolog", dalam Thohari Musnamar, et.al., (Ed.), Dasar-dasar Konseptual Bimbingan dan Konseling Islami. Yogyakarta: UII Press.

Munandar, Utami. (1997). Mengembangkan Bakat dan Kreativitas Anak Sekolah. Jakarta: Gramedia. 
Munib, Dul. (2016). "Manajemen Pembinaan Mental Rohani Islam Prajurit di Markas Kodam II/Sriwijaya" Jurnal Concelia, 12(1). http://jurnal.radenfatah.ac.id/index.ph p/conciencia/article/view/3414.

Napitupulu, Dedi Sahputra. (2017). "Dasar-Dasar Konseling dalam AlQur'an” Jurnal Al-Irsyad, 7(2). http://jurnal.uinsu.ac.id/index.php/alirsyad/article/view/6701.

Nurihsan, Ahmad Juntika. (2006). Bimbingan \& Konseling dalam Berbagai Latar Kehidupan. Bandung: Refika Aditama.

Pieter, Herri Zan. (2012). Pengantar Psikopatologi untuk Keperawatan. Jakarta: Kencana.

Rahayu, Iin Tri. (2009). Psikoterapi: Perspektif Islam \& Psikologi Kontemporer. Malang: UIN-Malang Press.

Sitorus, Musa Hotmatua, et.al. (2019). "Peran Pembinaan Mental Komando Armada I dalam Meningkatkan Operasi Prajurit” Jurnal Pertahanan dan Bela Negara, 9(3). http://139.255.245.6/index.php/JPBH/ article/view/638.

Subagyo, P. Joko. (1991). Metodologi Penelitian; Teori dan Praktek. Jakarta: Rineka Cipta.

Sutirna. (2012). Bimbingan dan Konseling. Bandung: Andi.
Suwardana, Hendra. (2017). "Revolusi Industri 4.0 Berbasis Revolusi Mental" Jurnal Jati Unik, 1(2). http://ojs.unikkediri.ac.id/index.php/jatiunik/article/ view/117/0.

Tim Penyusun. (2002). Ensiklopedi Islam. Jakarta: Ichtiar Baru van Hoeve.

Warka, I Wayan. (2018). "Implementasi Pembinaan Mental Fungsi Komando Sumber Daya Manusia di Lantamal III Jakarta" Jurnal Strategi Pertahanan Laut, 4(3). http://jurnalprodi.idu.ac.id/index.php/ $\underline{\text { SPL/article/view/376. }}$

Zaini, Ahmad. (2016). “Terapi Sufistik untuk Penyembuhan Gangguan Mental dan Mewujudkan Pribadi yang Sehat" Konseling Religi: Jurnal Bimbingan Konseling Islam, $\quad 8(1)$. https://journal.iainkudus.ac.id/index.php/k onseling/article/view/Ahmad\%20Zaini. 